\title{
Student's access and performance in the Portuguese Higher Education: Issues of gender, age, socio-cultural background, expectations, and program choice
}

\author{
Acesso e desempenho dos estudantes no Ensino Superior \\ em Portugal: Questões de género, origem sócio-cultural, percurso académico, \\ expectativas, escolha do curso e idade dos estudantes
}

\author{
Maria Eugénia Ferrão ${ }^{1}$ \\ ${ }^{1}$ Universidade da Beira Interior | Faculdade de Ciências | Departamento de Matemática \\ Covilhã | Portugal. Contato: meferrao@ubi.pt \\ http://orcid.org/0000-0002-1317-0629
}

\author{
Leandro S. Almeida ${ }^{2}$ \\ ${ }^{2}$ Universidade do Minho | Instituto de Educação \\ Braga | Portugal. Contato: leandro@ie.uminho.pt \\ http://orcid.org/0000-0002-0651-7014
}

Abstract: The purpose of this article is to characterize and contribute to the debate on the democratization of
Portuguese higher education, both in terms of access and the performance of students enrolled in a
public university. The analyses concern the sociodemographic characteristics and schooling trajectory
of the 2,697 students enrolled for the first time in the University of Minho in the academic year $2015 / 16$.
The relationships between such characteristics and the choice of program, expectations regarding higher
education, the criteria of admission, and the association with their permanence and performance in the
first year of studies are explored as well. Several statistical tests were applied, such as those based on
multivariate analysis of variance, chi-squared test for the independence between variables, or the t-
Student test for the comparison of means of two independent samples. Results suggest that student's
gender, socio-cultural background and schooling trajectory are related to the choice of the programe,
university entrance score and the entrance option. The multivariate analysis of variance of student's
grade point average at the end of the first year suggests the influence of the interaction between the
fixed term of scientific-disciplinary area of the program attended and the program option of access to
higher education. We did not find any statistically significant association between socio-cultural
background and permanence in higher education; i.e, the socio-cultural origin of the students does not
seem to influence the decision to abandon, suspend or transfer program, at least during their first year
of studies. Our findings suggest student's resilience and/or institutional action meaning a step further
on the path for social equity in the Portuguese higher education.

Key words: Access to higher education. Persistence. Academic success. Gender. Socio-cultural background.

Resumo: O artigo tem o propósito de caracterizar e contribuir para o debate sobre a democratização do Ensino Superior português, quer no que se refere ao acesso como ao desempenho dos estudantes matriculados numa universidade pública. Analisam-se características sociodemográficas e percurso escolar dos 2697 alunos inscritos pela $1^{\mathrm{a}}$ vez no $1^{\circ}$ ano no ano letivo 2015/16 e a sua associação à escolha do curso, às expectativas sobre o ensino superior, condições de ingresso, bem como a associação com o desempenho ao longo do $1^{\circ}$ ano. Os principais resultados indicam que o sexo, a origem socio-cultural das famílias e o percurso escolar estão associados à escolha do curso, à nota de candidatura e à opção de entrada. A análise de variância multivariada da classificação no final do $1^{\circ}$ ano sugere que, ao nível de significância de 5\%, o termo fixo de área científico-disciplinar e os termos de interacção entre opção do curso e área científica-disciplinar são estatisticamente diferentes de zero. Não foi encontrada associação estatisticamente significativa de origem socio-cultural com persistência no ensino superior. A origem dos estudantes parece não influenciar a decisão de abandonar, suspender ou transferir-se de curso, pelo menos durante $\mathrm{o} 1^{\mathrm{o}}$ ano. Os resultados associados ao percurso escolar sugerem a resiliência e/ou a acção institucional na promoção da equidade no ensino superior.

Palavras-chave: Acesso ao ensino superior. Persistência. Sucesso académico. Género. Origem socio-cultural. 
DOI: http://dx.doi.org/10.1590/S1414-40772019000200006

Este é um artigo publicado em acesso aberto (Open Access) sob a licença Creative Commons Attribution Non-Commercial, que permite uso, distribuição e reprodução em qualquer meio, sem restrições desde que sem fins comerciais e que o trabalho original seja corretamente citado. https://creativecommons.org/licenses/by-nc/4.0/

https://creativecommons.org/licenses/by-nc/4.0/

\section{Introduction}

The turn of the century in Europe was marked by the growth of the number of students enrolled in Higher Education (HE), with a rate of 116\% in 2002 (reference year 1998). Such considerable growth was verified in every UE-25 European countries, except Italy (99\%), Austria (90\%) and Bulgaria (88\%) (SANTOS SILVA et al., 2005). The Portuguese HE is organized as a binary system, with university education oriented toward the provision of solid academic training, combining the efforts and responsibilities of teaching and research units, while polytechnic education concentrates on vocational and advanced technical training that are professionally oriented (ASSEMBLEIA DA REPÚBLICA, 2007). The Ministry of Science, Technology and HE (MCTES, Ministério da Ciência, Tecnologia e Ensino Superior) regulates the public system of $\mathrm{HE}$ by controlling the access conditions, guaranteeing the accreditation and the quality assessment of programs and institutions, and funding institutions and students in financial need. Portuguese governments use access to HE to regulate the system and its subsectors. For that purpose, the MCTES sets the number of vacancies in every study programme, which is known by the numerus clausus. Thus, students' access is based on a national competition with a centralized placement system, which gives priority to those with larger admission scores. Students have to rank a maximum of six preferences, each is composed of undergraduate programme-institution pair. Considering the reference year 1998, the annual variation in Portugal in the number of HE students has always been larger than 100\%, approaching this value in 2015, and reaching a maximum of $115 \%$ in 2003 . The great expansion of Portuguese HE took place following the 1970s, materializing in the principle of equal opportunities underlying the revolution of April 1974. The number of students attending HE in the early 70s was approximately 60,000 and in 2002/3 was nearly 400,000, which represents a variation of more than $650 \%$. These figures show the democratization of access to higher education. Another relevant index is the variation in the number of students enrolled for the first time in the first year of a programme. The absolute number always increased up to 2011, 
representing a variation of $161 \%$ compared to the reference year 1998. Such a process of expansion has also increased the heterogeneity of the student population, regarding the students' origin from urban or rural regions, their schooling trajectory, and socioeconomic and cultural background, among other aspects. Moreover, a sheer raise in the number of students is no way to support the hypothesis of a "democratization". That would be only the case if students from disadvantaged social statuses would be increasingly participating. In fact, the percentage of HE students who received a scholarship was $12.5 \%$ in 1998 and $19.9 \%$ in 2017 (DGEEC/MEd - MCTES, DGES/MCTES, 2018). This means that, in addition to the increasing number of students enrolled, the percentage of those who come from disadvantaged social backgrounds and receive financial support has also increased. Even though, the democratization of access was mainly based on the creation of places of learning, with insufficient attention to the quality of education and training. Since "dropout and failure rates mainly penalize students from the most disadvantaged social strata" (ALMEIDA; MARINHO-ARAUJO; AMARAL; DIAS, 2012, p. 913), some researchers differentiate the notion of "democratization of access" from the "democratization of success". The institutional research conducted by Almeida, Guisande, Soares e Saavedra (2006), demonstrated the influence of student' sociodemographic characteristics (such as gender, family socio-cultural capital) on his/her transition from secondary to higher education, in particular on the programme choice and on the university entrance score, as well on the grade point average (GPA) at the end of the first year. A decade later, due to the fast growth of the system, questions about the quality of education and the student' success persistently emerge. In this sense, based on data collected in the academic year $2015 / 16$, we pursue similar type of research questions in order to assess changes related to the "democratization of quality" in higher education. We return to the analysis of the influence of gender and socio-cultural origin of the students on the student's university entrance scores (which considers the secondary education classification with the grade of the entrance examination to higher education), the area of programme, and on the average obtained by the student at the end of the first year (GPA). We widen the scope of analysis by adding relevant individual variables and outcomes, such as the age upon admission, the expectations of students entering higher education, and the student's persistence in the first year. That is, we incorporate the recommendation that the phenomena of access, permanence and dropout must be studied together. Thus, among other specific objectives, we seek evidence to answer the following research questions: Is the student's access to HE influenced by sociodemographic factors such as gender or socio-cultural origin? Is the student' success in HE, assessed by student's 
persistence and student's GPA, influenced by socio-demographic factors such as gender and socio-cultural origin? How the access and success have changed over the last decade in HE?

\section{Topics on the Portuguese Higher Education}

The recent report published by the Portuguese office for education statistics, refers that the performance of the HE system is characterized by a high rate of evasion and failure. According to the Directorate General of Education and Science Statistics (ENGRÁCIA; BAPTISTA, 2018), considering the students enrolled for the first time in a three-year undergraduate courses in the academic year 2011/12, after four years $(2014 / 15), 46 \%$ of them had obtained a diploma; 14\% were still enrolled in the same programme; $11 \%$ attended a different programme from the one in which they had been firstly enrolled, and the remaining $29 \%$ were not found in the Portuguese HEsystem. Actually, the problem of dropping out is a central HE research topic of international scope (GEORG, 2009; MEGGIOLARO; GIRALDO; CLERICI, 2017; SALES; HEIJMANS; SILVA, 2017; SERPA; PINTO, 2000; VITELLI, 2016) to which institutional research (ALTBACH, 2014; ALTBACH; ENGBERG, 2001) has contributed a great deal.

The main explanatory factors of (in)success in HE refer to highly interdependent processes, such as learning, teaching and evaluation (ALMEIDA, 2002). Thus, failure varies according to the programmes and/or disciplines, with higher probability of occurrence in the first or second year of studies, and greater incidence in the realm of the exact sciences and engineering. The authors (FERRÃO; ALMEIDA, 2018b) applied a multilevel logistic regression model to data collected from students enrolled for the first time in the first year at the University of Minho in the academic year 2015/16, and they found quantitative based evidence of the long-term effect of student's failure at primary school level (ISCED 2) on the probability of his/her persistence in HE (ISCED 5), as well as the effect of the university admission criteria, such as whether s/he was admitted to her/his first option programme and the student's university entrance score. Multi-institutional research, e.g. Rhee (2008), points out the role of institutional selectivity on the odds of student' stopping out as well as transferring. In another study, the authors (FERRÃO; ALMEIDA, 2018a) applied a Gaussian response multilevel model to the same cohort of students' data and found that the university admission criteria seems to be associated with the grade point average (GPA) obtained by the student at the end of the 1st year, taking into account student's sociodemographic variables. Such findings also suggest that the linear relationship between student's university entrance score and first 
year GPA varies randomly across programmes - suggesting the programme specificity - even after controlling by the area of study. The findings also showed that male students older than 19 years are less likely to persist in the first year of higher education. Thus, these results indicate that dropout in $\mathrm{HE}$ is multivariate, highlighting the impact of a heterogeneous set of personal and institutional variables and, above all, their interaction, confirming the theoretical model proposed by (TINTO, 2010; TINTO; CULLEN, 1973).

Empirical studies have shown that the determinants affecting the temporary cessation and course transference are different from those influencing dropout. For example, Rhee (2008) differentiates the type of student's withdrawal by categorizing them in four groups, i.e, those who stop out, drop out, transfer, or persist. Based on a sample size of 3,947 students, the author showed that "The odds of dropping out and transferring relative to persistence were 1.23 and 1.12 times greater for minority students, respectively." (p. 174-175) and also that "the odds of dropping out relative to persistence were higher for older students, but lower for those with higher socioeconomic status" (p. 178). Another example is the study by Pascarella et al. (1981) that is illustrative of the differential effects of individual factors on dropout, temporary interruption or transfer of programme/institution. Specifically, they sought to determine the predictive power of pre-entry characteristics on student persistence, suspension, or dropout. The authors verified differences in patterns of discrimination among the three phenomena. The process of admission to higher education, including the conditions of access and choice of institution and programme, also have an effect on persistence and success of the students (ALMEIDA et al., 2006; ENGLISH; UMBACH, 2016; SALES et al., 2017; SOARES; RIBEIRO; CASTRO, 2001).

In summary, when relating some personal variables, the studies show that students from families with higher socioeconomic levels have a higher rate of permanence and graduation, and this situation may be associated with the fact that these young people bring more academic skills from secondary education, surpassing the curricular requirements in $\mathrm{HE}$ with greater ease. Alternatively, it may be associated with the frequency of programmes of study with greater social prestige (ALMEIDA et al., 2006) or students who do not need to reconcile studies with work activities that are necessary to finance their studies (LETKIEWICZ et al., 2014). Almeida et al. (2006) also suggest that the choice of the programme has a determining role in the reconstitution and reproduction of the established social hierarchy, since the "generalized and apparent openness democratization of access to tertiary education will eventually integrate differentiations from previous school trajectory, the choice of course and the success rates associated with gender and the socio-cultural background of the students" (ALMEIDA et al., 
p. 513). More than a decade after the cohort of data that supports this assertion, we return to the objectives of that study to see if there were any changes over time.

\section{Methodology}

\section{Ethical statement}

The study protocol was in accordance with ethical standards (OECD, 2007). The students were informed of the objectives and they gave informed written consent, also allowing access to their grades (GPA) at the end of the first semester and at the end of the first year, according to the explanation given (ALMEIDA; CASTRO, 2016). No incentives were provided for students' participation in the study.

\section{Participants and variables}

The sample consists of 2,697 first year students who enrolled in the University of Minho, a public university in the north of Portugal, in the academic year 2015/2016. The data used for the purpose of this study are related to the student's academic trajectories and their individual attributes, as well as to the outcome variables in the first year of studies. Specifically, in regard to the outcome variables, we considered: Persistence (1: if the student reached the end of the 1st year with academic performance assessed by GPA, 0: otherwise). The percentage of persistent students is $72 \%$, and average GPA is 13.48 ( $\mathrm{SD}=1.66$ ), on a scale of $0-20$. Descriptive analysis of the data shows the majority of the students are female (57\%), chose the University of Minho as their first option (72\%), enrolled in their first option programme (59\%), are full time students $(91.9 \%)$, and they have always been promoted in primary or secondary education (83.3\%). Age is the student's chronological age in September 2014. The mean age of these students is 18.9 (SD 3.6) years, with a minimum of 16 and a maximum of 61 years. For the purpose of comparison with other studies, we recoded the initial measure with a dummy variable for students older than 19 years, which represent $13 \%$. The distribution of students by parents' education shows that for $34.4 \%$ of the students, neither father nor mother have more than basic education and that for $15.7 \%$ of the students, both father and mother have a HE diploma. The average university entrance score is 152.39 (DP 18.91) points ( 0 -200 point scale), with a minimum of 105 and a maximum of 200 points. Almost half the students (47\%) attend a STEM (science, technology, engineering or mathematics) degree programme, $17 \%$ are registered in Economics, Administration or Public Administration, 13\% in Humanities, 10\% in 
the Social Sciences, $8 \%$ in Nursing), and 5\% in Law. Table 1 contains some descriptives of student performance.

Table 1 - Descriptive statistics of students' performance

\begin{tabular}{c|r|r|r|r}
\hline Variable & Minimum & Maximum & \multicolumn{1}{c}{ Mean } & \multicolumn{1}{c}{ Standard deviation } \\
\hline University entrance score & 105 & 200 & 152.39 & 18.91 \\
\hline Persistence & 0.00 & 1.00 & 0.72 & 0.45 \\
\hline Grade Point Average & 10.00 & 18.92 & 13.48 & 1.57 \\
\hline
\end{tabular}

\section{Instruments}

For the purpose of this paper, data were mainly collected by administering two questionnaires: Academic Perceptions Questionnaire - Expectations (APQ-E) (ALMEIDA; DEAÑO et al., 2012). This instrument explores students' beliefs and aspirations in the transition to higher education, namely, what they expect to find and to develop. Its items combine cognitive and motivational aspects of academic experience and covered several dimensions: (a) Training for job and career development; (b) Personal and social development; (c) International student mobility; (d) Political engagement and citizenship; (e) Social pressure; (f) Training quality in the course; and (g) Living together and social interaction. Students rate their agreement with item content on a 6-point Likert-type scale ranging from 1 (completely disagree) to 6 (completely agree). From the intercorrelations among the seven dimensions, a general factor of expectations was estimated given by principal component analysis (JOLLIFFE, 2002; NICHOLSON; PUTWAIN; CONNORS; HORNBY-ATKINSON, 2013).

Socio-academic questionnaire. Students answered several short questions reporting personal information related to previous academic trajectory and parents' ${ }^{\prime}$ academic degrees, if the programme and the university are their first option.

\section{Statistical methods}

The statistical methods applied were chosen according to the nature of the variables involved and the respective research questions.

We applied chi-squared hypothesis testing based on contingency tables wherever both variables were qualitative. For variables related to student access to higher education, we tested the association between the scientific-disciplinary area of the programme and gender, sociocultural origin, age upon admission; we tested the association between the option of entering the programme and gender, socio-cultural origin, and age upon admission. For the variable 
related to student success - persistence in the first year - we tested the association with gender, socio-cultural origin and age upon admission.

We applied Student's t-test hypothesis test in order to compare the means in two independent samples to explore the existence of a pattern between variables in which one is quantitative and the other is qualitative with two categories. That is, for example, student's expectations or university entrance scores with gender or entrance option. We also used the same hypothesis test to compare the final mean (GPA) by gender, by age at admission or by entry option.

Finally, we used Analysis of Variance to test the fixed effects of the 1st order and respective interactions of the variables gender, socio-cultural origin, age at admission, scientific-disciplinary area of the programme and programme option, in the final mean of the first year (GPA).

\section{Results}

The results are presented in two subsections, so that the first includes the characterization of students and the conditions of access into HE and the second subsection includes the characterization of the academic performance of students in the first year of studies.

\section{Characterization of students and admission conditions}

We consider a student who has not dropped out, has not suspended his/her studies, or has not moved on to another programme to be persistent. Descriptive statistics for the subset of non-persistent students show that they are generally older, more likely to have failed in primary and/or secondary school, and have, on average, lower entry grades into university.

Table 2 shows the distribution of students by each of the course areas (NES: Natural and Exact Sciences, ENG: Engineering, SOC: Social Sciences, ECO: Economics, management and business, HUM: Humanities, Health) according to gender and socio-cultural origin (low, middle, high). Is shows that the gender pattern mentioned 10 years earlier by Almeida et al. (2006) is maintained in the choice of programmes; i.e., while most of the male students from any socio-cultural background attend engineering courses (between 64.18\% and 67.49\%), they are minority in the social and economic sciences courses from any socio-cultural group (between $32.82 \%$ and $36.96 \%$ ). 
Table 2 - Empirical distribution of students by field of study, per gender and socio-cultural background

\begin{tabular}{cccccccccccccc}
\hline $\begin{array}{c}\text { Socio- } \\
\begin{array}{c}\text { cultural } \\
\text { background }\end{array}\end{array}$ & Gender & & SES & ENG & \multicolumn{3}{c}{$\begin{array}{c}\text { SOC+ } \\
\text { ECO }\end{array}$} & & HUM & & Health & Total \\
\hline \multirow{2}{*}{ Low } & Male & 48 & 36.36 & 164 & 67.49 & 85 & 32.82 & 25 & 24.51 & 4 & 8.51 & 326 \\
& Female & 84 & 63.64 & 79 & 32.51 & 174 & 67.18 & 77 & 75.49 & 43 & 91.49 & 457 \\
\hline \multirow{2}{*}{ Middle } & Male & 94 & 52.81 & 267 & 64.18 & 119 & 34.39 & 32 & 26.45 & 17 & 18.48 & 529 \\
& Female & 84 & 47.19 & 149 & 35.82 & 227 & 65.61 & 89 & 73.55 & 75 & 81.52 & 624 \\
\hline \multirow{2}{*}{ High } & Male & 27 & 55.10 & 97 & 64.67 & 34 & 36.96 & 7 & 41.18 & 11 & 23.40 & 176 \\
& Female & 22 & 44.90 & 53 & 35.33 & 58 & 63.04 & 10 & 58.82 & 36 & 76.60 & 179 \\
\hline
\end{tabular}

Such a pattern is even more pronounced in the humanities where, in the "low" and "middle" groups, the ratio of percentages is approximately 3 . That is, on average, there are approximately three females for every male attending these courses. In health science programmes the ratio is also in favor of the female students. Among the 47 students in the low socio-cultural group, $91.49 \%$ are female; among the 92 in the middle socio-cultural group, $81.52 \%$ are women and, finally, in the "high" group, the percentage of women is $76.6 \%$ among the 47 students. A more detailed analysis of the frequencies according to origin and gender by each of the programmes included shows that part of such an advantage is due to the nursing course, mainly in the group of low socio-cultural origin, in which $65.1 \%$ of the women are in the undergraduate degree programme in nursing and $34.9 \%$ are in the integrated Master's degree in medicine. On the other hand, the distribution of students by area of study according to age, shown in Table 3, shows that among students with a college entrance age of younger than 20 years, $35 \%$ attend an engineering course, while that percentage is $18.5 \%$ among students aged 20 years or older. In this group of students, almost $70 \%$ attend a course in the area of the social sciences, economics or humanities.

Table 3 - Empirical distribution of students by area of study, per age

\begin{tabular}{cc|c|c|c|c|c}
\hline & \multicolumn{5}{c|}{ Area of study } & \\
\cline { 2 - 6 } Age & SES & ENG & SOC+ECO & HUM & Health & Total \\
\hline Age $<20$ & 340 & 759 & 665 & 222 & 195 & 2181 \\
& $(15.6 \%)$ & $(34.8 \%)$ & $(30.5 \%$ & $(10.2 \%)$ & $(10.2 \%)$ & $(100 \%)$ \\
\hline Age $\geq 20$ & 24 & 60 & 119 & 108 & 14 & 325 \\
& $(7.4 \%)$ & $(18.5 \%)$ & $(36.6 \%)$ & $(33.2 \%)$ & $4.3 \%)$ & $(100 \%$ \\
\hline Total & 364 & 819 & 784 & 330 & 209 & 2506 \\
& $(14.5 \%)$ & $(32.7 \%)$ & $(31.3 \%)$ & $(13.2 \%)$ & $(8.3 \%)$ & $(100 \%)$ \\
\hline
\end{tabular}


In order to reinforce the descriptive analysis, we applied the non-parametric chi-squared hypothesis test to check non-independence between the variables gender and area of study $\left(\chi^{2}\right.$ $=274.78$, $\mathrm{p}$ value $<0.001)$, origin and area of study $(\chi 2=46.52$, p value $<0.001)$, and age and area of study $(\chi 2=161.03, \mathrm{p}$ value $<0.001)$, and the associations observed were always statistically significant.

Regarding the expectations of the students, the hypothesis test for the comparison of the mean in independent samples was applied to compare the groups defined by gender and age. As for the first comparison, for Student's t-test statistic, $t=11.16(\mathrm{p}<.001)$ and for the second one we obtained $\mathrm{t}=7.58(\mathrm{p}<.001)$. That is, both hypothesis tests indicate statistically significant differences, at the $1 \%$ level, of the expectations by sex or age. As for the hypothesis test to verify the differentiation of expectations by socio-cultural origin, we applied the ANOVA test with a factor, the result of which is $F=2.174(p=0.114)$ indicating the non-rejection of the null hypothesis, according to which the groups of socio-cultural origin do not differ in expectations.

The ANOVA applied to the relationship between expectations and the study area presents $\mathrm{F}=5.73$ ( $\mathrm{p}$ value $<0.001)$ statistic, suggesting that there are statistically significant differences in student expectations by area of study. The ANOVA results also suggest the differentiation of student's university entrance score based on socio-cultural group $(\mathrm{F}=78.73$, $\mathrm{p}<.001)$ and scientific-disciplinary area $(\mathrm{F}=120.24, \mathrm{p}<.001)$. The hypothesis test for the comparison of student's university entrance score based on gender suggests a statistically significant advantage in favor of the women $(t=4.98, \mathrm{p}<.001)$, while the average of that variable is statistically higher in the group of students with an age of admission younger than 20 years $(\mathrm{t}=2.42, \mathrm{p}<.001)$.

Finally, the chi-squared hypothesis test suggests the association between gender and option of admission into the programme $(\chi 2=17.81, \mathrm{p}<.001)$, between socio-cultural origin and option of admission $(\chi 2=6.145, \mathrm{p}<.05)$, and between age and option of admission $(\chi 2=$ $9.349, \mathrm{p}<.01)$.

\section{Students' performance: Persistence and GPA}

We did not find a statistically significant association between socio-cultural origin and persistence $(\chi 2=3.8, p$ value $=0.15)$, but the results suggest that persistence is a phenomenon marked by gender differentiation $(\chi 2=4.39$, $\mathrm{p}$ value $<0.05)$. The variable age of admission also seems to be associated with the probability of persistence. While $78 \%$ of students under the age 
of 20 are persistent, $67 \%$ of students aged 20 or older are not persistent $(\chi 2=299.21$, p value < 0.001). The hypothesis test suggests that persistence is related to entry option. That is, at the $5 \%$ level of significance, we reject the null hypothesis according to which the entry option and persistence are independent $(\chi 2=28.28, \mathrm{p}<.001)$. Therefore, we also found an association between the scientific-disciplinary area of the programme that the student attends and persistence $\left(\chi^{2}=46.2, \mathrm{p}<.001\right)$. Regarding student expectations, the hypothesis test for the comparison of the mean in independent samples was applied to compare the group of persistent students with the group of non-persistent students. The results obtained indicate statistically significant differences in expectations $(t=4.39$, $\mathrm{p}$ value $<0.001)$.

The hypothesis test for the comparison of GPAs between male and female students indicates a statistically significant difference $(\mathrm{t}=8.52, \mathrm{p}<.001)$. We applied the ANOVA test with a factor to verify the effect of socio-cultural origin on GPA. The results suggest a statistically significant difference among groups $(\mathrm{F}=8.39, \mathrm{p}<.001)$. The analyses of variance performed to test whether age of admission (less than 20 years vs. equal or greater), scientificdisciplinary area and option of entrance are also factors of differentiation of GPA. The results of the F statistic are presented in Table 4.

Table 4 - One way ANOVA hypotheses tests

\begin{tabular}{c|c|c}
\hline Fator & $\mathrm{F}$ & $\mathrm{p}$ value \\
\hline Age $>19$ & 0.152 & 0.696 \\
Area of study & 85.88 & $<0.001$ \\
Entry option & 81.33 & $<0.001$ \\
\hline
\end{tabular}

The analysis of variance with these three factors jointly, as well as with socio-cultural origin and gender, and their first order interactions results in statistically significant fixed effects for coefficients associated with gender $(\alpha=10 \%)$, area of study $(\alpha=1 \%)$, interaction between course option and area of study $(\alpha=5 \%)$ and interaction between course option, socio-cultural origin and area of study $(\alpha=10 \%)$.

\section{Discussion}

Throughout this article, the sociodemographic conditions and expectations of a cohort of students enrolled for the first time in the first year of study are analyzed with the purpose of exploring the "democratization" of admission and the quality of learning in higher education. Table 5 summarizes the main results obtained from the study. Regarding the variables associated with transition to higher education, such as programme's scientific-disciplinary area 
chosen, student's expectations, university entrance score or course entry option, we found evidence of statistically significant differences by gender, socio-cultural origin, quality and age of the student. These results are in accordance with those reported by Almeida at al. (2006) for a cohort of students more than ten years ago. In fact, Almeida et al. (2006), when exploring the conditions of access and success in university, found "considerable differences, considering the gender, the socio-cultural capital of the families of origin and the quality of the students' schooling, in the choice of the type of course attended, in the university entrance score and in the GPA obtained ... " (p. 512). Our results now show that the gender trend in the choice of programmes by scientific-disciplinary area is maintained and, in addition, it is also verified in humanities and health-related programmes, in favor of women, specifically those in low and middle socio-cultural groups. The advantage is even greater in healthcare-related programmes, but to a great extent, that is due to the nursing programme.

Regarding the expectations of the student upon entrance into the university, they do not seem to vary according to the sociocultural group of origin of the student. Concerning the performance variables in the first year, we verified that the student's GPA varies according to gender, socio-cultural origin, scientific-disciplinary area and option of entry into the programme. In turn, student persistence is statistically associated with all the individual variables studied except for socio-cultural origin. That is, the students' socio-cultural origin does not seem to influence their decision to abandon, suspend or transfer programmes, at least during the first year, which corroborates the results obtained through the application of a multilevel logistic regression model in which the relationship between socio-cultural origin and persistence is controlled by individual variables such as gender, age, experience of no promotion up to the ninth year (ISCED 2), entry exam grade, and student's admission into the first option programme (Ferrão \& Almeida, 2018b). Such a result, to be confirmed throughout the programme, may be the manifest of an institutional equity policy that is worth noting, since it runs counter to previous results, according to which the phenomenon of abandonment and failure in HE especially penalized students from disadvantaged social strata (Almeida et al., 2006; Engrácia \& Baptista, 2018). In agreement with the results presented by Ferrão and Almeida (2018a), using the same cohort of students, the authors applied multilevel regression models to student's GPA, including as explanatory variables the familiar socio-cultural group, age, if the university is the first choice, and the scientific-disciplinary area. The findings suggest that the group of students with low socio-cultural origin have, on average, the classification at the end of the first year increased by 0.14 standard deviation compared to their colleagues from other socio-cultural origin. Such results, obtained by different methods of analysis, not only 
confirm the findings of this article but also give quantitative support to the conjecture advanced by Engrácia and Baptista (2018, p. 18), according to which

[...] children of parents with low schooling who, despite the contrary winds, can finish high school and enter higher education, will be, on average, young people with school performance and levels of resilience above average among students from disadvantaged backgrounds. Therefore, their subsequent performance in HE is expected to be more comparable to the performance of students from favored socioeconomic backgrounds.

In fact, the results presented in this paper and in Ferrão and Almeida (2018a), for the first time in Portugal, show the advantage in the GPA that students of disadvantaged sociocultural origin have compared to their colleagues, even after controlling for the remaining variables.

Considering that $34 \%$ of the students in the cohort in analysis belong to the group with a low socio-cultural background (both parents have no more than a 9th grade education (ISCED 2)) and that in the Portuguese population aged 15-64 years, this group represents 52\% (PORDATA, 2018); that in the cohort of students, 15\% belong to the group with a high sociocultural origin (both father and mother have HE level $(4<$ ISCED $\leq 6))$ and that such a group in the Portuguese population aged 15-64 represents $22 \%$, it seems that in addition to the conjecture "levels of student resilience," there is affirmative action in favor of the attenuation of social inequalities and, therefore, in the promotion of social equity. We need more work on this topic of research.

The results that refer to the pattern of programme choice by socio-cultural origin group are in agreement with what several authors have emphasized regarding the influence of the socioeconomic and cultural capital of the student in preference for more prestigious courses or institutions (TAVARES; TAVARES; JUSTINO; AMARAL, 2008; TAVARES; FERREIRA, 2012). According to Tavares et al. (2008), students from disadvantaged family backgrounds have a stronger preference for programmes related to teacher training and management, while students who have a privileged family background tend to choose programmes in the areas of law, art, health, or science and technology. 
Table 5 - Summary of main findings

\begin{tabular}{|c|c|c|c|c|c|c|c|}
\hline & & Gender & $\begin{array}{l}\text { Socio- } \\
\text { cultural } \\
\text { Origin } \\
\end{array}$ & Age & $\begin{array}{l}\text { Scientific- } \\
\text { disciplinar } \\
\text { Area }\end{array}$ & Expectations & $\begin{array}{l}\text { Entry } \\
\text { option }\end{array}$ \\
\hline \multirow[t]{4}{*}{ Access } & $\begin{array}{l}\text { Scientific- } \\
\text { disciplinary Area }\end{array}$ & Yes & Yes & Yes & --- & Yes & --- \\
\hline & Expectations & Yes & No & Yes & Yes & --- & Yes \\
\hline & $\begin{array}{l}\text { University entrance } \\
\text { score }\end{array}$ & Yes & Yes & Yes & Yes & Yes & --- \\
\hline & Entry option & Yes & Yes & Yes & --- & --- & --- \\
\hline Performance & $\begin{array}{l}\text { Persistence } \\
\text { GPA }\end{array}$ & $\begin{array}{l}\text { Yes } \\
\text { Yes }\end{array}$ & $\begin{array}{l}\text { No } \\
\text { Yes }\end{array}$ & $\begin{array}{l}\text { Yes } \\
\text { No }\end{array}$ & Yes $^{\text {Yes }}$ & $\begin{array}{l}\text { Yes } \\
---\end{array}$ & $\begin{array}{l}\text { Yes } \\
\text { Yes }\end{array}$ \\
\hline
\end{tabular}

\section{Conclusion}

The main objective of this paper is to characterize and contribute to the debate on the democratization of Portuguese higher education, both in terms of access and the performance of students enrolled in a public university. Our results suggest the association between student's sociodemographic variables (gender, age, sociocultural origin) and the variables that characterize the access to HE (scientific-disciplinary area of the programme, university entrance score and entry option), and also with the variables that characterize student's performance in the first year of studies (persistence and GPA), with the exception for the innovative result obtained on the relationship between sociocultural origin and student's persistency. In fact, such hypothesized association was not confirmed meaning a step further on the path for equity in higher education.

Some caution is needed regarding generalizing the results presented here because the study refers to the cohort of students from the University Minho in the year 2015/16. If other cohorts and/or other institutions had been selected, the results could be slightly different. From this perspective, it is very important to develop broader research involving samples from different cohorts of new entrants and multiple HE institutions in order to obtain national results.

\section{Declaration}

Availability of supporting data: The data that support the findings of this study are available from the University of Minho, but restrictions apply to the availability of these data, which were used under license for the current study, and so are not publicly available. Data are however available from the authors upon reasonable request and with permission of the University of Minho. 


\section{Acknowledgements}

This work was partially funded by FCT- Fundação para a Ciência e a Tecnologia through project number CEMAPRE - UID/MULTI/00491/2019.

\section{References}

ALMEIDA, L. S. Formatar o ensino a pensar na aprendizagem. In: POUZADA, A. S.; ALMEIDA, L. S.; VASCONCELOS, R. M. (eds.). Contextos e dinâmicas da vida académica. Guimarães: Universidade do Minho, 2002. p. 239-252.

ALMEIDA, L. S.; CASTRO, R. V. Ser estudante no ensino superior: Observatório dos percursos académicos dos estudantes da UMinho. In: ALMEIDA, L. S.; CASTRO, R. V. (eds.). Ser estudante no ensino superior: o caso dos estudantes do $1^{\circ}$ ano. Braga: Universidade do Minho, 2016. p. 1-14.

ALMEIDA, L. S.; DEAÑO, M. et al. Questionário de perceções académicas: Versão expectativas (QPA-E). Braga/Ourense: Universidade do Minho/Universidade de Vigo, 2012.

ALMEIDA, L. S.; GUISANDE, M. A.; SOARES, A. P.; SAAVEDRA, L. Acesso e sucesso no Ensino Superior em Portugal: questões de género, origem sócio-cultural e percurso académico dos alunos. Psicol. Refl. Crít., Porto Alegre, v. 19, n. 3, p. 507-514, 2006.

ALMEIDA, L. S.; MARINHO-ARAUJO, C. M.; AMARAL, A.; DIAS, D. Democratização do acesso e do sucesso no ensino superior: uma reflexão a partir das realidades de Portugal e do Brasil. Avaliação, Campinas; Sorocaba, v. 17, n. 3, p. 899-920, 2012.

ALTBACH, P. G. The emergence of a field: research and training in higher education.

Studies in Higher Education, Taylor \& Francis, v. 39, n. 8, p. 1306-1320, 2014.

ALTBACH, P. G.; ENGBERG, D. Higher education: a worldwide inventory of centers and programs. Phoenix: Oryx Press, 2001.

ASSEMBLEIA DA REPÚBLICA. Lei no 62/2007, Regime jurídico das instituições de ensino superior. Diário da República, $1^{\text {a }}$ série, n. 174, Portugal, 2007.

DGEEC/MEd - MCTES, DGES/MCTES, P. Bolseiros do ensino superior em \% de alunos matriculados no ensino superior: total e por subsistema de ensino, 2018.

ENGLISH, D.; UMBACH, P. D. Graduate school choice: An examination of individual and institutional effects. The Review of Higher Education, Baltimore, v. 39, n. 2, p. 173-211, 2016.

ENGRÁCIA, P.; BAPTISTA, J. O. Percursos no ensino superior: situação após quatro anos dos alunos inscritos em licenciaturas de três anos. Lisboa: Direção-Geral de Estatísticas da Educação e Ciência, 2018. 
FERRÃO, M. E.; ALMEIDA, L. S. Differential effect of university entrance score on firstyear students' academic performance in Portugal. Assessment \& Evaluation in Higher Education, Taylor \& Francis, v. 44, n. 4, p. 612-622, 2018 a.

FERRÃO, M. E.; ALMEIDA, L. S. Multilevel modelling of persistence in higher education. Ensaio: Aval. Pol. Públ. Educ., Rio de Janeiro, v. 26, n. 100, p. 664-683, 2018 b.

GEORG, W. Individual and institutional factors in the tendency to drop out of higher education: A multilevel analysis using data from the Konstanz Student Survey. Studies in Higher Education, Taylor \& Francis, v. 34, n. 6, p. 647-661, 2009.

JOLLIFFE, I. T. Principal component analysis. New York: Springer, 2002.

LETKIEWICZ, J. et al. The path to graduation: factors predicting on-time graduation rates. Journal of College Student Retention: Research, Theory \& Practice, SAGE, v. 16, v. 3, p. 351-371, 2014.

MEGGIOLARO, S.; GIRALDO, A.; CLERICI, R. A multilevel competing risks model for analysis of university students' careers in Italy. Studies in Higher Education, Taylor \& Francis, v. 42, n. 7, p. 1259-1274, 2017.

NICHOLSON, L.; PUTWAIN, D.; CONNORS, L.; HORNBY-ATKINSON, P. The key to successful achievement as an undergraduate student: Confidence and realistic expectations? Studies in Higher Education, Taylor \& Francis, v. 38, n. 2, p. 285-298, 2013.

OECD. Best Practices for Ensuring Scientific Integrity and Preventing Misconduct. Paris: OECD Publishing, 2007.

PORDATA. População residente com 15 e mais anos: total e por nível de escolaridade completo mais elevado, 2018. Available in: https://www.pordata.pt/Portugal/Popula\%25C3\%25A7\%25C3\%25A3o+residente+com+15+e +mais+anos+total+e+por+n $\% 25 \mathrm{C} 3 \% 25 \mathrm{ADvel}+\mathrm{de}+\mathrm{escolaridade+completo+mais+elevado-}$ 2101. Access in: 14 mar. 2018.

RHEE, B. S. Institutional climate and student departure: a multinomial multilevel modeling approach. The Review of Higher Education, Johns Hopkins University, v. 31, n. 2, p. 161$183,2008$.

SALES, P. E. N.; HEIJMANS, R. D.; SILVA, C. E. G. Análise multinível da transição estudantil do curso técnico para o ensino superior. Estudos em Avaliação Educacional, São Paulo, v. 28, n. 69, 2017.

SANTOS SILVA, M. et al. Concepção estratégica das intervenções operacionais no domínio do ensino superior. In: ESTUDOS temáticos para preparação do próximo ciclo de intervenções estruturais 2007-2013. Lisboa: Observatório do QCAIII, 2005.

SERPA, L. F. P.; PINTO, N. M. A. C. A evasão no ensino superior no Brasil. Estudos em Avaliação Educacional, São Paulo, n. 21, p. 109-145, 2000. 
SOARES, J. F.; RIBEIRO, L. M.; CASTRO, C. de M. Valor agregado de instituições de ensino superior em Minas Gerais para os cursos de Direito, Administração e Engenharia Civil. Dados, Rio de Janeiro, v. 44, n. 2, p. 363-396, 2001.

TAVARES, D.; TAVARES, O.; JUSTINO, E.; AMARAL, A. Students' preferences and needs in Portuguese higher education. European Journal of Education, John Wiley \& Sons Ltd, v. 43, n. 1, p. 107-122, 2008.

TAVARES, O.; FERREIRA, J. B. Choices and motivations: the why and how of Portuguese students' enrolment choices. European Journal of Education, John Wiley \& Sons, v. 47, n. 2, p. 310-326, 2012.

TINTO, V. From theory to action: exploring the institutional conditions for student retention. In: SMART, J. C. (ed.). Higher Education: handbook of theory and research. Dordrecht: Springer, 2010. p. 51-89.

TINTO, V.; CULLEN, J. Dropout in higher education: a review and theoretical synthesis of recent research. New York: Columbia University, 1973.

VITELLI, R. F. Evasão escolar na educação superior: de que indicador estamos falando? Estudos em Avaliação Educacional, São Paulo, v. 27, n. 66, p. 908-937, 2016. 